\title{
INDIANA'S MALPRACTICE SYSTEM: NO-FAULT BY ACCIDENT?
}

\author{
Eleanor D. Kinney* and William P. Gronfein**
}

INTRODUCTION

This article reviews Indiana's ten years of experience with medical malpractice tort and insurance reforms. Indiana's malpractice reforms were among the first comprehensive malpractice reforms in the nation, have withstood several constitutional challenges, and have undergone few major changes since 1975. ${ }^{1}$ A model for other states ${ }^{2}$ and the federal government, ${ }^{3}$ these reforms have helped Indiana health care providers continue to enjoy low malpractice premiums compared to other states. ${ }^{4}$ Both health care providers and insurers are highly satisfied with the system. ${ }^{5}$ Recently, however, press reports have galvanized consumer concerns about whether the reforms promote the interests of providers and insurers over those of claimants. ${ }^{6}$

Copyright (C) 1991 by Law and Contemporary Problems

* Professor of Law and Director, The Center for Law and Health, Indiana University School of Law-Indianapolis.

** Assistant Professor of Sociology, Indiana University-Indianapolis.

The research in this article was funded by Grant No. 12416 from The Robert Wood Johnson Foundation's Medical Malpractice Program, Eleanor D. Kinney, J.D., M.P.H., Principal Investigator, $1987-1990$.

The authors wish to thank the following individuals for their invaluable contributions on this article: Morris Weinberger, Charles Slemenda, Tim Quigley, Janine Wallick, Thomas Gannon, Julie Ann Randolph, Trudie Pursell, Phyllis Bonds, Geoffrey Segar, Randall Bovbjerg, and Walter Wadlington. The views expressed in the article are solely the authors'.

1. See Cha v Warmick, 476 NE2d 109, 114 (Ind 1985); Rohrabaugh v Wagoner, 274 Ind 661, 664 68, 413 NE2d 891, 894-95 (1980); Johnson v St. Vincent Hosp., Inc., 273 Ind 374, 386-408, 404 NE2d 585, 591-606 (1980); Whitaker v St. Joseph's Hosp., 415 NE2d 737, 745-46 (Ind App 1981); Lee v Lafayette Home Hosp., Inc., 410 NE2d 1319, 1320-21 (Ind App 1980). Contrast Hines v Elkhart General Hosp., 465 F Supp 421, 431-34 (ND Ind 1979), aff'd, 603 F2d 646 (7th Cir 1979).

2. See, for example, Kan Stat Ann \$§ 60.3407, 65.4901 (Kan Dep't Admin, 1985 \& 1989 Supp); La Rev Stat Ann § 40.1299.49 (West, 1977 \& 1990 Supp); Neb Rev Stat $\$$ 2801-2855 (West, 1988); Randall R. Bovbjerg, Legislation on Medical Malpractice: Further Developments and a Preliminary Report Card, 22 UC Davis L Rev 499, $521-31$ (1989).

3. See generally Dept of Health \& Human Services, Description of Model Health Care Provider Liability Reform Act (December 1987); Dept of Health \& Human Services, Report of the Task Force on Medical Liability and Malpractice (August 1987).

4. See notes $143-47$ and accompanying text.

5. See US Gen Acct'g Office, Medical Malpractice: Case Study on Indiana 2 (December 1986) ("GAO, Case Study on Indiana").

6. See Joseph T. Hallinan \& Susan M. Headden, A Case of Neglect: Medical Malpractice in Indiana, Indianapolis Star 1 (June 24, 1990); Joseph T. Hallinan \& Susan M. Headden, State Failing to Crack Down on Malpractice, Indianapolis Star 1 (June 25, 1990); Joseph T. Hallinan \& Susan M. Headden, Malpractice Laws Stacked Against Victims: Doctors, Insurance Companies Reap Biggest Benefils, Indianapolis 
This article analyzes the history and operation of the reforms, focusing on Indiana's Patient Compensation Fund ("PCF") and the comprehensive cap on all damages. The PCF and its cap on damages are among the most substantial legal changes of any state's, ${ }^{7}$ and have the greatest impact on the most seriously injured claimants. Part II describes Indiana's Medical Malpractice Act ("the Act"), ${ }^{8}$ and analyzes its practical application. Part III compares Indiana's experiences under the Act with neighboring states' experiences and with national data on malpractice claims, claimants, and defendants. As shown by the data, the unique characteristics of the Act and its implementation have led to quite generous payment of large claims with surprisingly little consideration . of the defendants' fault. These results suggest that Indiana may have implemented, quite accidentally, a compensation system for large medical malpractice claims containing many key characteristics of no-fault compensation systems. ${ }^{9}$

\section{II}

\section{The Indiana Medical Malpractice Act}

\section{A. Background}

Indiana is a conservative jurisdiction whose statutory and case law in the tort law field favors defendants. ${ }^{10}$ The state has a modified comparative fault statute (although medical malpractice claims are exempted) that, unlike pure comparative fault statutes, adopts the more conservative approach allowing recovery only when the defendant's fault exceeds the plaintiff's. ${ }^{11}$ Additionally, in 1986, Indiana modified the common law collateral source rule, making evidence of other sources of compensation for the plaintiff's injury admissible at trial. ${ }^{12}$ Finally, Indiana's wrongful death statute, unlike the more generous statutes of some other states, precludes recovery for emotional loss even for the death of children. ${ }^{13}$ It is not surprising then that

Star 1 (June 26, 1990). See also Isabel Wilkerson, As Indiana Debates its Malpractice Law, So Does the Country, NY Times (National) All (August 20, 1990).

7. See Bovbjerg, 22 UC Davis L Rev at 525 (cited in note 2).

8. Ind Code Ann $\S 16-9.5$ (Burns, 1990).

9. See notes 157-71 and accompanying text.

10. See John F. Vargo, 1983 Survey of Recent Developments in Indiana Law: Torts, 17 Ind L Rev 341 , 385 (1984); Robert G. Ziegler, 1984 Survey of Recent Developments in Indiana Law: Torts, 18 Ind L Rev 417, 425-27 (1985).

11. Ind Code Ann § 34-4-33-4 (1986); L. Larson, 1 Comparative Negligence: Law and Practice $\$ 2.30$ (Matthew Bender, 1990); see Lawrence P. Wilkins, The Indiana Comparative Fault Act at First (Lingering) Glance, 17 Ind L Rev 687 (1984); Victor E. Schwartz, Comparative Negligence in Indiana: A Unique Statute that Will Reshape the Law, 17 Ind L Rev 957, 963-64 (1984).

12. Act of March 11, 1986, Pub L No 201-1986, 1986 Ind Acts 1969, codified at Ind Code Ann $\S \S 34-4-36-1$ to 3 (Burns, 1988). See generally Lawrence P. Wilkins, $A$ Multi-Perspective Critique of Indiana's Legislative Abrogation of the Collateral Source Rule, 20 Ind L Rev 399 (1987).

13. Ind Code Ann $\S \S 34-1-1-1$ to 2 (1990); see Stuart M. Speiser, 1 Recovery for Wrongful Death $\S 1: 12-14$ at 32-38 (Lawyers Co-Op, 2d ed 1975). 
Indiana has adopted, and its courts have upheld, what are arguably the nation's strictest set of tort and insurance reforms for medical malpractice. ${ }^{14}$

In the early 1970s, Indiana, along with the rest of the nation, experienced a crisis in the cost and availability of medical malpractice insurance for its health care providers. ${ }^{15}$ Indiana, like other states, experienced sharp increases in the size and frequency of medical malpractice claims. ${ }^{16}$ Consequently, the availability of medical malpractice insurance for physicians and hospitals decreased sharply in the mid-1970s. ${ }^{17}$ In January 1975, Governor Otis R. Bowen, himself a physician, called in his State of the State address for reform of the common law tort system for medical malpractice. ${ }^{18}$

On February 4, 1975, House Bill 1460 ("H 1460"), drafted by attorneys for the Indiana State Medical Association, was introduced into the Indiana House of Representatives. ${ }^{19} \mathrm{H} 1460$ called for an independent administrative tribunal, composed of physicians, lawyers, and consumers, to adjudicate malpractice claims and award damages and attorneys' fees according to fixed schedules and formulas. ${ }^{20}$ When it became clear that most Indiana senators opposed the bill as too radical a departure from the common law jury system, the Indiana Senate considered a flurry of amendments that introduced elements of the current Act. Throughout, the legislature deliberated in an atmosphere of crisis. Physicians packed the galleries as the legislators debated. As one attorney recalls, "The entire House chamber was full of doctors-yelling, screaming .... [I]t was the damnedest thing you've ever seen.",21

14. See Frank A. Sloan \& Randall R. Bovbjerg, Medical Malpractice: Crisis, Response and Effects, Health Ins Ass'n Am Res Bull 13 (May 1989).

15. See generally Otis R. Bowen, Medical Malpractice Law in Indiana, $11 \mathrm{~J}$ Legis 15 (1984). See also Adam Benjamin, Jr., Indiana's Medical Malpractice Crisis, in David Warren \& Richard Merritt, eds, A Legislator's Guide to the Medical Malpractice Issue 38 (Health Policy Center, Graduate School, Georgetown University, and National Conference of State Legislatures, 1976).

16. The frequency of claims filed against physicians between 1970 and 1975 increased $42 \%$, and the average damage award increased from $\$ 12,993$ in 1970 to $\$ 34,297$ in 1975 , with medical malpractice insurance premiums for physicians rising $410 \%$ during the same period. Indiana Medical Malpractice Study Commission, Final Report 5-6 (1976) ("IMMSC Final Report").

17. See Mansur $v$ Carpenter, No 37281, slip op 4 (Hancock County Cir Ct, April 6, 1978); IMMSC Final Report at 5-6 (cited in note 16).

In the summer of 1974, St. Paul Fire and Marine Insurance Company advised nearly 1,000 Indiana physicians that it would not renew their malpractice insurance. The Medical Protective Company, Indiana's major malpractice insurer for physicians, sharply limited the amount of insurance it would write for individual physicians. Similarly, in 1974 and early 1975 , the seven major malpractice insurers for hospitals discontinued or limited writing liability insurance for hospitals. In response, many Indiana hospitals curtailed emergency and surgery services because of the high cost of liability insurance or lack of insured physicians to staff these services. Mansur, No 37281 at 4.

18. Message of Governor Otis R. Bowen to the 99th General Assembly, First Session, Jourmal of the House 31-36 (January 9, 1975). See also Benjamin, Indiana's Medical Malpractice Crisis at 38 (cited in note 15); Bowen, $11 \mathrm{~J}$ Legis at 15 (cited in note 15).

19. See Benjamin, Indiana's Medical Malpractice Crisis at 39 (cited in note 15).

20. Id at $39-40$.

21. Hallinan \& Headden, June 26, 1990 Indianapolis Star at 8 (cited in note 6). 
This activity culminated on April 17, 1975, when the Indiana General Assembly enacted the Act. ${ }^{22}$ The Act's purpose was to provide health care professionals and institutions with affordable medical malpractice insurance and thus assure the continued availability of health care services in the state. ${ }^{23}$ Shortly after the Act was passed, medical malpractice premiums in Indiana dropped, and insurance became readily obtainable again. ${ }^{24}$

\section{B. The Act's Provisions}

The Act contains three major reforms: (1) a comprehensive cap on damages, (2) mandated medical review before trial, and (3) a state-run insurance fund to pay large claims (the PCF). Through 1989, the cap on medical malpractice recoveries was $\$ 500,000.25$ The legislature raised the cap to $\$ 750,000$ for claims occurring after January 1,1990 , presumably in recognition of a need to address inequities in the system for persons with large claims. ${ }^{26}$

Eligible health care providers, exhaustively defined in the statute, ${ }^{27}$ participate voluntarily by proving "financial responsibility." In this context, financial responsibility means a specified level of primary malpractice insurance coverage. Health care providers also participate by paying a surcharge on their primary insurance coverage to finance the PCF. ${ }^{28}$ The level of primary insurance coverage for physicians and other health care providers is $\$ 100,000$ per occurrence and $\$ 300,000$ total. ${ }^{29}$ Nearly all Indiana physicians and about 90 percent of Indiana hospitals participate. ${ }^{30}$ Nonparticipants are protected neither by the damage cap nor by the PCF. ${ }^{31}$

22. Act of April 17, 1975, Pub L No 146-1975, 1975 Ind Acts 854, codified as amended at Ind Code $\$ 16-9.5$ (1990).

23. Report of the Committee on Labor and the Economy to the 99th General Assembly, First Session, Joumal of the House 577-78 (March 5, 1975). See Bowen, $11 \mathrm{~J}$ Legis at 15 (cited in note 15); Benjamin, Indiana's Medical Malpractice Crisis at 39-40 (cited in note 15); Johnson, 273 Ind at 379-80, 404 NE2d at 589-90; Mansur, No 37281 at 6-7.

24. GAO, Case Study on Indiana at 2 (cited in note 5); Michael S. Mullen, Update on the Indiana Law of Medical Malpractice, in Indiana Medical Malpractice S-13 to S-14 (Medical Protective Co., Fort Wayne, 1984) (materials prepared for Indiana Continuing Legal Education Forum) ("Update").

25. Ind Code Ann \& 16-9.5-2-2(b)-(c).

26. Act of May 2, 1989, Pub L No 189-1989 \& 1, 1989 Ind Acts 1538, codified as amended at Ind Code Ann \& 16-9.5-2-2. The Indiana State Medical Association, the Indiana Hospital Association, and the Indiana Trial Lawyers Association entered an agreement, subsequently communicated to the legislative leadership by memorandum on March 1, 1989, to support this increase in the cap and not to support a legislatively mandated study of the Act until after January 1, 1993. Memorandum to Michael K. Phillips, Paul S. Mannweiler, Robert D. Garton, and Dennis P. Neary.

27. Ind Code Ann $\$ 16-9.5-1-1$.

28. Id at $\S 16-9.5-2-1(a)$.

29. Id at $\$ 16-9.5-2-6(a)$. As of 1985 , small hospitals (fewer than 100 beds) must carry $\$ 2$ million in annual aggregate insurance, larger hospitals must carry $\$ 3$ million, and prepaid health care delivery plans must carry $\$ 700,000$. Act of April 14, 1985, Pub L No 177-1985, § 3, 1985 Ind Acts 1391, codified at Ind Code Ann \$ 16-9.5-2-6.

30. Telephone interview between Julie Ann Randolph, assistant director, Center for Law and Health, and Dianna J. Pitcher, manager, Medical Malpractice Division, Indiana Department of Insurance (September 18, 1990).

31. Ind Code Ann $\$ 16-9.5-1-5$. 
1. The Medical Review Panel. The Act specifies that malpractice claimants must file their claims with the Indiana Department of Insurance and go through a medical review panel before proceeding to trial. ${ }^{32}$ As of 1985, however, claimants can opt out and proceed directly to court if all parties agree to forgo panel review. ${ }^{33}$ Also as of 1985 , claimants with claims under $\$ 15,000$ can unilaterally opt out. ${ }^{34}$ At any point, the parties may settle the claim. Further, the PCF may consider and pay the claim without a medical review panel opinion. ${ }^{35}$

For the remaining claimants, the medical review panel provides an informal process to encourage an early decision on liability and can thereby facilitate quick resolution of the claim. ${ }^{36}$ The panel consists of one attorney, who serves as nonvoting chair, and three health care providers. ${ }^{37}$ The parties select the attorney who will serve as chair. ${ }^{38}$ Each party selects one provider panelist, and those two provider panelists select the third. ${ }^{39}$ Each party may challenge the third panelist without the need to show cause. ${ }^{40}$ When requested, providers must serve on medical review panels except in cases of serious hardship. ${ }^{41}$ The panel review process is designed to take less than nine months. ${ }^{42}$

The panel is authorized solely to give expert opinion on the cause of the injury and on the defendant's liability, or to determine that a material issue of fact bears on liability. ${ }^{43}$ The panel has no role in determining damages, unlike its counterpart in some other states. ${ }^{44}$ The panel receives evidence and reviews the discovery made by the parties, and can also consult independent medical authorities. ${ }^{45}$ The panel's opinion is admissible at trial, but is not conclusive evidence of causation or liability; either party can compel any panel member to testify at trial at that party's expense. ${ }^{46}$

32. Id at $\S \S 16-9.5-1-6 ; 16-9.5-9-1,16-9.5-9-2,16-9.5-9-2.1$. Any party may request a medical review panel by filing a request with the Indiana Commissioner of Insurance. Id at $\$$ 16-9.5-9-1.

33. Act of April 14, 1985, Pub L No 177-1985, $\$ 8$, codified as amended at Ind Code Ann $\$ 16$ 9.5-9-2(b).

34. Act of April 18, 1985, Pub L No 178-1985, § 5, 1985 Ind Acts 1402, codified as amended at Ind Code Ann $\$ 16-9.5-9-2.1$.

35. Ind Code Ann § 16-9.5-4-3.

36. Note, Constitutionality of the Indiana Medical Malpractice Act: Re-Evaluated, 19 Valp U L Rev 493, 494 (1985) (authored by Catherine Schick Hurlbut); James D. Kemper, Myra C. Selby \& Bonnie K. Simmons, Reform Revisited: A Review of the Indiana Medical Malpractice Act Ten Years Later, 19 Ind L Rev 1129,1131 (1986).

37. Ind Code Ann $\$ 16-9.5-9-3$

38. Id at $\$ 16-9.5-9-3(a)$.

39. Id at $\$ 16-9.5-9-3(\mathrm{~b})$.

40. Id at $\S 16-9.5-9-3(\mathrm{~b})(3)$

41. Id at $\$ 16-9.5-9-3(\mathrm{~b})(4)$.

42. According to statutory deadlines found in Ind Code Ann $\S 16-9.5-9-3$, convening the panel should take less than two months. Once selected, the panel must meet and make its decision within 180 days. Id at $\$ 16-9.5-9-3.5$. See Kemper, Selby \& Simmons, 19 Ind L Rev at 1133 (cited in note 36).

43. Ind Code Ann $\$ 16-9.5-9-7$.

44. See Sloan \& Bovbjerg, Health Ins Ass'n Am Res Bull at 13 (cited in note 14).

45. Ind Code Ann $\S \S$ 16-9.5-9-4(a), 16-9.5-9-6.

46. Id at $\S 16-9.5-9-9$. 
2. The Patient Compensation Fund. The PCF, administered by the Indiana Department of Insurance and financed by a surcharge on a provider's primary malpractice insurance, ${ }^{47}$ pays large claims to the extent they exceed $\$ 100,000$ - that is, when the primary insurer of one or more defendants agrees to settle a claim for at least $\$ 100,000$, or (more rarely) when a court renders a verdict in excess of $\$ 100,000.48$ As of 1985 , primary insurers and the PCF can make periodic payments to claimants, ${ }^{49}$ with no limit on the actual value of the total payment that ultimately comes to the claimant. ${ }^{50}$ There is a 15 percent limit on attorneys' fees that are based on recoveries from the PCF. ${ }^{51}$

The primary insurer (or the uninsured health care provider) generally pays claims up to $\$ 100,000.52$ These claims are resolved privately through settlements, the customary way in which claims have been resolved under the common law tort system since the widespread advent of liability insurance. ${ }^{53}$

To be eligible for PCF payment, the primary insurer of one or more defendants must settle a claim for $\$ 100,000$, or a court must enter a judgment for more than $\$ 100,000 .{ }^{54}$ Until 1985 , one defendant had to contribute $\$ 100,000$, part of which could be paid in the future, toward the claimant's recovery before a case was eligible for the PCF. ${ }^{55}$ However, since 1985, at least $\$ 75,000$ must be paid at settlement; such a payment, coupled with a commitment to a future payment of $\$ 25,000$, qualifies for PCF payment. ${ }^{56}$ Most importantly, more than one insurer can contribute to the requisite amount of primary insurance (although one insurer must pay at least $\$ 50,000$ at the time of settlement). ${ }^{57}$ The cost of an annuity or similar form of security for a structured settlement is counted in the requisite amount of primary insurance to be paid at settlement. ${ }^{58}$

To obtain funds from the PCF, a claimant must petition the court for approval of a settlement or payment of a judgment. ${ }^{59}$ The other parties and/or the Commissioner of Insurance may contest the petition, and the

47. Id at $\$ 16-9.5-4-1$ (1990 \& 1990 Supp).

48. Id at $\$ 16-9.5-2-7$.

49. Act of April 14, 1985, Pub L No 179-1985 § 1, 1985 Ind Acts 1403, codified as amended at Ind Code Ann $\$ \$ 16-9.5-2-2.1$ to 2.4. See Robin B. Stickney, 1985 Amendments to the Indiana Medical Malpractice Act, 19 Ind L Rev 403, 405 (1986).

50. Ind Code Ann $\$ 16-9.5-2-1(a)$.

51. Id at $\S 16-9.5-5-1($ a).

52. Id at $\$ 16-9.5-2-2(d)$.

53. See generally H. Laurence Ross, Settled Out of Court: The Social Process of Insurance Claims Adjustment (Aldene, 2d ed 1980); Fleming James, Jr. \& John V. Thornton, The Impact of Insurance on the Law of Torts, 15 L \& Contemp Probs 430 (Summer 1950).

54. Ind Code Ann $\$ 16-9.5-2-2(d)$. If a provider's aggregate insurance $(\$ 300,000)$ has been exhausted, the entire claim can be paid from the PCF according to a procedure that is substantially similar to that for claims above $\$ 100,000$ according to $\$ 16-9.5-2-7$.

55. Id at $\$ 16-9.5-4-3$.

56. Id at $\S 16-9.5-2-2.2(b)$.

57. Id at $\$ 16-9.5-2-2.2(\mathrm{c})$.

58. Id at $\$ 16-9.5-2-2.2(\mathrm{~b})$.

59. Id at $\$ 16-9.5-4-3(1)$. 
court may even convene an evidentiary hearing on damages. ${ }^{60}$ No judicial review of a court-approved settlement is available. ${ }^{61}$ In the PCF and associated court proceedings, the liability of the health care provider is admitted and established. ${ }^{62}$

3. Other Key Provisions. The Act contains several other important provisions, including a shortened statute of limitations ${ }^{63}$ and the establishment of the Residual Malpractice Insurance Authority, which offers primary insurance for physicians unable to obtain private insurance. ${ }^{64}$ The Act also requires that the disposition of any malpractice claim be reported to the Indiana Department of Insurance by counsel and insurers. ${ }^{65}$

Finally, the Act establishes some linkages with Indiana's formal medical discipline system. Specifically, the Act requires that the Commissioner of Insurance report to the appropriate licensure or registration boards the settlements and judgments against each health care professional for review of his or her continued fitness to practice. ${ }^{66}$ The board may then, if deemed appropriate, proceed with various disciplinary actions against the health care provider, including censure, or the probation, suspension, or revocation of the provider's license. ${ }^{67}$

\section{III}

\section{INDIANA'S EXPERIENCE UNDER REFORMS}

This section reviews data on the operation of Indiana's malpractice reforms as well as data collected on all malpractice claims filed with the Indiana Department of Insurance from 1975 through 1988.68 This analysis also relies on claims data from the Medical Protective Company of Fort Wayne, Indiana-the largest insurer of physicians in the state.

60. Id at $\S \S 16-9.5-4-3(3), 16-9.5-4-3(5)$.

61. Id.

62. Id at $\S 16-9.5-4-3(5)$.

63. Id at $\$ 16-9 \cdot 5-3-1$. The statute of limitations has been amended to require a claimant to file a malpractice claim within two years of the alleged malpractice, although minors under age six have until age eight to file a claim. Id.

64. Id at $\S \S 16-9.5-8-2,16-9.5-8-6$.

65. Id at $\S 16-9.5-6-1(b)$.

66. Id at $\S 16-9.5-6-2(a)$.

67. Id. In practice, the various professional disciplinary authorities have taken little or no action on reported malpractice settlements and judgments, generating considerable public concern recently. See Hallinan \& Headden, June 25, 1990 Indianapolis Star at l (cited in note 6).

68. From 1987 through 1990, the Center for Law and Health at Indiana University School of Law-Indianapolis conducted an evaluation of Indiana's Medical Malpractice Act. The evaluation collected data on all opened and closed claims filed with the Indiana Department of Insurance from 1975 through 1988 . These materials are on file at the Center. 


\section{A. General Trends}

From 1975 through $1988,6,225$ malpractice claims were filed with the Indiana Department of Insurance. 69 Of these claims, only 2,074 were closed. ${ }^{70}$ It is remarkable that under Indiana's model malpractice reforms, less than one-third of filed claims were closed over a twelve-year period.

1. Claim Frequency and Severity. The key characteristics of claims affecting the availability and affordability of medical malpractice insurance are their frequency and their severity (that is, their size in dollar terms). ${ }^{71}$ Increases in claim frequency and severity helped trigger the two malpractice crises of the $1970 \mathrm{~s}$ and 1980s. ${ }^{72}$ Most legislated tort and insurance reforms are aimed at controlling the frequency and severity of claims. ${ }^{73}$

Despite the reforms adopted, Indiana, like other states, experienced increases in claim frequency in the 1980s. Table I presents data on the number of new claims opened per physician from 1977 through 1988. While actual annual frequency in Indiana is lower than in other states, the rate of increase in the frequency of Indiana's malpractice claims is comparable to national trends, ${ }^{74}$ with claim frequency in the state increasing by 70 percent between 1980 and 1985 .

Between 1975 and 1988, the mean claim severity in current dollars for paid Indiana claims was $\$ 130,855$ ( $\$ 89,350$ for all claims; $\$ 12,231$ for paid, non-PCF claims). The median was $\$ 14,000$. The mean paid claim in 1977 constant dollars was $\$ 73,566$, and the median was $\$ 7,684$. A study combining data collected by the National Association of Insurance Commissioners ("NAIC") 75 and United States General Accounting Office ("GAO")76

69. Indiana Department of Insurance, Indiana Patient's Compensation Fund as of December 31 , 1988, 3 (1988).

70. Id. A claim file is considered "closed" when (1) a claim for damages is not made, (2) the plaintiff drops the claim, (3) the insurer and plaintiff agree to a financial settlement, (4) a court renders a verdict, or (5) a settlement is reached through arbitration. US Gen Acct'g Office, Medical Malpractice: Characteristics of Claims Closed in 1984, 14 (April 1987) ("GAO, Characteristics of Claims Closed"). In this study, the determination that a claim was closed was made by the Indiana Department of Insurance, based on these criteria but also often requiring the reporting of information on settlement from the parties and involved insurers.

71. See Sloan \& Bovbjerg, Health Ins Ass'n Am Res Bull at 7 (cited in note 14).

72. See id at 2-7; Glen O. Robinson, The Medical Malpractice Crisis of the 1970s: A Retrospective, 49 L \& Contemp Probs 5 (Spring 1986); Patricia M. Danzon, The Frequency and Severity of Medical Malpractice Claims: New Evidence, 49 L \& Contemp Probs 57 (Spring 1986); Frank A. Sloan, State Responses to the Malpractice Insurance "Crisis" of the 1970s: An Empirical Assessment, $9 \mathrm{~J}$ Health Pol, Pol'y \& L 629 (Winter 1985).

73. See Sloan \& Bovbjerg, Health Ins Ass'n Am Res Bull at 13-14 (cited in note 14).

74. Id at 7, Figure 2. See also US Gen Acct'g Office, Six State Case Studies Show Claims and Insurance Costs Still Rise Despite Reforms 17-18 (December 1986) ("GAO, Six Case Studies"); GAO, Case Study on Indiana at 14-15 (cited in note 5).

75. Nat'l Ass'n Insurance Commissioners, Medical Malpractice Closed Claims, 1975-1978 (1980) ("NAIC, Medical Malpractice Closed Claims").

76. GAO, Characteristics of Claims Closed (cited in note 70). 


\section{TABLE 1}

Frequency and Severity of Indiana Malpractice Claims, 1977-1988

\begin{tabular}{cccc} 
Year & $\begin{array}{c}\text { Mean Paid Claim } \\
\text { Current } \$\end{array}$ & $\begin{array}{c}\text { Mean Paid Claim } \\
\text { Constant } 1977 \$\end{array}$ & $\begin{array}{c}\text { Claims Per } 100 \\
\text { Physicians }^{\mathrm{b}}\end{array}$ \\
\hline 1977 & $\$ 4,166$ & $\$ 4,166$ & 2.2 \\
1978 & 53,760 & 49,935 & 4.1 \\
1979 & 79,531 & 66,398 & 4.7 \\
1980 & 74,264 & 54,615 & 5.7 \\
1981 & 26,625 & 17,740 & 6.1 \\
1982 & 85,674 & 53,731 & 7.6 \\
1983 & 11,719 & 67,952 & 8.3 \\
1984 & 128,511 & 74,975 & $9.0^{\text {d }}$ \\
1985 & 135,925 & 76,569 & 9.7 \\
1986 & 186,387 & 103,012 & 8.5 \\
1987 & 220,697 & 117,674 & 8.0 \\
1988 & 37,988 & 19,460 & -
\end{tabular}

SouRcE: Indiana Malpractice Claims Database, The Center for Law and Health, Indiana University School of Law-Indianapolis, 1988; Indiana Department of Insurance, 1988.

a Indiana Malpractice Claims Data Base, The Center for Law and Health, Indiana University School of Law-Indianapolis, 1990.

b Id.

c Indiana Department of Insurance, American Medical Association 1988.

d AMA physician data unavailable for 1984-figure obtained by taking average of 1983 and 1985 .

- AMA physician data not yet available for 1988.

reported a national mean severity for paid claims at $\$ 102,313$, using 1984 constant dollars. ${ }^{77}$

Claim severity in Indiana also increased substantially over time. Table I presents data on mean paid claim severity from 1977 through 1988.78 Between 1978 and 1987, the mean paid claim severity in constant 1977 dollars rose from $\$ 49,935$ to $\$ 117,674$, an increase of more than 135 percent. Nationally, the severity of paid claims doubled in real dollars between 1980 and $1986 .{ }^{79}$ Basically, then, Indiana's experience with claim severity has been similar to national trends despite its malpractice reforms.

2. Unique Patterns in Indiana Claim Severity. About 32 percent of Indiana's closed claims settled without payment; this figure is considerably smaller than the 57 percent found by GAO in its study of claims closed in $1984 .{ }^{80}$ This difference is interesting because it suggests either (1) that the operation of Indiana's malpractice reforms negatively influences the initial decisions of

77. Frank A. Sloan, Paula M. Mergenhagen \& Randall R. Bovbjerg, Effects of Tort Reforms on the Value of Closed Medical Malpractice Claims: A Microanalysis, 14 J Health Pol, Pol'y \& L 663, 688, Appendix 2 (Winter 1989).

78. Although data on closed claims included claims filed as early as 1975 , none of these earlier claims were settled before 1977. Also, the table "endpoints" (1977 and 1988) are excluded from consideration because the number of claims settled in those years was much lower than the number of claims settled from 1978 through 1987.

79. Sloan \& Bovbjerg, Health Ins Ass'n Am Res Bull at 7 (cited in note 14).

80. GAO, Characteristics of Claims Closed at 19 (cited in note 70). 
plaintiffs' attorneys to bring a claim or (2) that malpractice insurers have a more expansive view toward settlement.

The distribution of Indiana's mean paid claim severity is especially interesting. Specifically, very few claims settled between $\$ 25,000$ and $\$ 100,000$ (12 percent) compared with the national data in GAO's study of 1984 closed claims (28.5 percent). ${ }^{81}$ Large Indiana claims $(\$ 100,000$ or more) constituted 30.2 percent of the total, compared with 18.3 percent in the GAO study. ${ }^{82}$ However, the proportion of small claims (less than $\$ 25,000$ ) in Indiana, 57.9 percent, and in the GAO study, 53.2 percent, were similar. ${ }^{83}$ Moreover, only 14 out of 2,074 claims ( 0.5 percent) closed under Indiana's reforms from 1975 through 1988 were paid at levels between $\$ 75,000$ and $\$ 100,000$. The unique patterns of Indiana's mean claim severity are quite important and, as will be discussed below, suggest that Indiana's system may be working in a highly unusual fashion. ${ }^{84}$

3. Claim Disposition Time. An average of 23.7 months elapsed between the time a claim was filed and when it was closed, with virtually no difference between paid and nonpaid claims. Interestingly, Indiana's average was almost two months shorter than the GAO study of 1984 claims. ${ }^{85}$ Like other national studies, ${ }^{86}$ larger claims in Indiana took longer than smaller claims.

4. Characteristics of Indiana Malpractice Claimants. Of Indiana's malpractice claimants, 59.5 percent were female and $\mathbf{4 0 . 5}$ percent were male. While this disparity represents a statistically significant difference from Indiana's population generally, it is quite similar to the percentages of 56.9 and 43.1 , respectively, found in the $1984 \mathrm{GAO}$ study of closed claims. ${ }^{87}$ It is well documented that women seek more health care services on average than men, due in part to childbearing needs. ${ }^{88}$ This may explain the large representation of women among malpractice claimants.

Men, however, tended to receive larger claim payments than women, receiving $\$ 105,909$ on average compared to $\$ 78,887$ for women. The mean paid claim payment for men was $\$ 157,709$ and $\$ 114,188$ for women, a highly significant difference. ${ }^{89}$ This disparity can perhaps be explained in part by the fact that men continue to command higher salaries than women, which

81. Id at 20 .

82. Id.

83. Id.

84. See notes $157-60$ and accompanying text

85. GAO, Characteristics of Claims Closed at 35 (cited in note 70) (indicating an average elapsed time of 25.1 months between the filing and closing of a claim). See also Sloan, Mergenhagen \& Bovbjerg, $14 \mathrm{~J}$ Health Pol, Pol'y \& $\mathrm{L}$ at 688, Appendix 2 (cited in note 77) (indicating an average elapsed time of 1.97 years).

86. GAO, Characteristics of Claims Closed at 35 (cited in note 70).

87. Id at 28.

88. Lu Ann Aday, Ronald Andersen \& Gretchen V. Fleming, Health Care in the United States: Equitable for Whom? 104 Table 3.4 (Sage Publications, 1980).

89. The difference is significant at $\mathrm{p}<.001$. This indicates that the probability of such a finding occurring by chance is less than .001 . 
translates into higher awards for lost wages. But this difference also suggests that, in practice, male lives may be generally valued more highly than female lives.

Data showed that the ages of Indiana claimants were relatively similar in distribution to the age data reported by GAO. ${ }^{90}$ Newborns received the highest mean award of any age category $(\$ 230,592)$, although as a group they constituted only 6.4 percent of the total number of claimants. These awards are almost certainly higher because injuries suffered at birth are likely to require expensive, often lifelong, care. Other differences between age groups were not significant.

5. Characteristics of Indiana Malpractice Claims. Most malpractice injuries in Indiana from 1975 through 1988 occurred in hospitals (68.3 percent, versus 22.2 percent in physicians' offices or clinics). GAO found that 80 percent of injuries occurred in hospitals, compared to 13 percent in physicians' offices nationally. ${ }^{91}$

The predominant allegation of negligence åmong Indiana's closed claims was surgical error, followed by errors in diagnosis and treatment. ${ }^{92}$ These were the same top three categories in GAO's study of claims closed in $1984 .^{93}$ Further, the distribution of severity of injury ${ }^{94}$ closely parallels the distribution reported by the GAO study. Finally, as in the GAO study, award size varied directly with severity..$^{95}$

6. Characteristics of Indiana Malpractice Defendants. Physicians and hospitals accounted for about 80 percent of the 4,230 malpractice defendants in the closed claims under Indiana's malpractice reforms through 1988. Of all reported defendants, nearly 60 percent were individual physicians, roughly 7 percent were physician professional corporations, 8 percent were other health professionals, and approximately 25 percent were hospitals and other health care institutions. More than 75 percent of claims involved just one or two

90. GAO, Characteristics of Claims Closed at 28 (cited in note 70).

91. Id at 24. See also Sloan, Mergenhagen \& Bovbjerg, $14 \mathrm{~J}$ Health Pol, Pol'y \& L at 688 , Appendix 2 (cited in note 77).

92. Allegations of negligence were classified according to the categories developed by the Risk Management Foundation of the Harvard Medical Institutions. Harvard Risk Management Foundation, Risk Management Foundation Information System (1987).

93. GAO, Characteristics of Claims Closed at 23 (cited in note 70).

94. Severity of injury was classified according to the nine-level system used in other studies: (1) emotional only (for example, fright); (2) insignificant (for example, lacerations, contusions, rash); (3) minor temporary disability (for example, infections, improperly set fractures leading to delayed recovery); (4) major temporary disability (for example, burns, surgical material left in patient, recovery delayed); (5) minor permanent partial disability (for example, loss of fingers); (6) major permanent partial disability (for example, deafness, loss of limb, loss of one kidney); (7) major permanent total disability (for example, paraplegia, brain damage); (8) grave permanent total disability (for example, quadriplegia, severe brain damage); and (9) death. NAIC, Medical Malpractice Closed Claims at 8 (cited in note 75). See GAO, Characteristics of Claims Closed at 41 (cited in note 70).

95. GAO, Characteristics of Claims Closed at 41 (cited in note 70). See also Randall R. Bovbjerg, et al, Juries and Justice: Are Malpractice and Other Personal Injuries Created Equal?, 54 L \& Contemp Probs 5 (Winter 1991); Frank A. Sloan \& Chee Ruey Hsieh, Variability in Medical Malpractice Payments: Is the Compensation Fair?, 24 L \& Soc'y Rev 601 (Fall 1990). 
defendants. This is not surprising given that one defendant must pay a substantial portion of the requisite $\$ 100,000$ to get a claim to the PCF. ${ }^{96}$ In claims with a physician as defendant, no settlement or judgment was made or reached in almost 54 percent of the cases. About one third of physician defendants were either obstetricians, general surgeons, or orthopedic surgeons. This is also consistent with the distribution nationally. ${ }^{97}$

Of all specialties, obstetricians represented the largest single group of malpractice defendants (14.5 percent), with general surgeons a close second (14.2 percent). These specialty groups, along with anesthesiologists, orthopedic surgeons, and radiologists, were overrepresented compared to their respective proportions of Indiana's physician population, while physicians in family practice, internal medicine, and psychiatry were underrepresented. ${ }^{98}$

About 55 percent of Indiana's physician defendants were board certified, compared to 50 percent reported in the GAO study. ${ }^{99}$ Also, about 20 percent of the Indiana physician defendants were educated in foreign medical schools, compared to 23 percent nationally. ${ }^{100}$ There were no statistically significant differences between board certified physicians and nonboard certified physicians, nor between foreign medical graduates and physicians educated in the United States, in terms of whether a claim was paid on their behalf.

Hospitals constituted about one-fourth of the defendants in all Indiana closed claims between 1975 through 1988. Private, nonprofit hospitals accounted for 69.9 percent of hospital defendants, a proportion substantially higher than their representation among Indiana's general acute care hospitals (48.1 percent). On the other hand, public hospitals made up only 29.4 percent of hospital defendants, and for-profit hospitals comprised 0.2 percent of hospital malpractice defendants. Of Indiana's general acute care hospitals, 45.1 percent are public and 6.8 percent are investor-owned. ${ }^{101}$

\section{B. Performance of the System}

1. Operation of the Cap. A controversial issue is the fairness of Indiana's comprehensive damage cap. Intuitively, comprehensive damage caps seem unfair to plaintiffs with large claims; they impose a limit on possible compensation that bears no relation to the damages the plaintiff actually sustained. Indeed, several state courts have invalidated damage caps on grounds that they deny plaintiffs their property rights. ${ }^{102}$ Only California has

96. See notes 54-58 and accompanying text.

97. GAO, Characteristics of Claims Closed at 55 (cited in note 70).

98. These trends are similar to results of a study of Florida physician defendants. Frank A Sloan, et al, Medical Malpractice Experience of Physicians: Predictable or Haphazard?, $262 \mathrm{~J}$ Am Med Ass'n 3291, 3292-94 (1989).

99. GAO, Characteristics of Claims Closed at 58 (cited in note 70).

100. Id at 59 .

101. Am Hosp Ass'n, Guide to the Health Care Field: 1988 Edition Al19-A124 (Am Hosp Ass'n, 1989).

102. See, for example, Wright v Central DuPage Hosp. Ass'n., 63 Ill 2d 313, 347 NE2d 736 (1976); Armeson v Olson, 270 NW2d 125 (ND 1978); Carson v Maurer, 120 NH 925, 424 A2d 825 (1980); 
a court-sanctioned damage cap, but it applies only to noneconomic losses. ${ }^{103}$ Nevertheless, empirical research repeatedly demonstrates that damage caps are one of the few tort reforms that effectively reduce the severity of malpractice claims. ${ }^{104}$

In assessing the operation of. Indiana's cap, comparisons with two neighboring states regarding large $(\$ 100,000$ or more) malpractice claims are instructive. ${ }^{105}$ Unlike Indiana, Michigan and Ohio have only sporadically adopted malpractice reforms and have never implemented a damage cap. ${ }^{106}$ However, with respect to other, more general tort reforms, all three states are rather similar. ${ }^{107}$ Also, in terms of aggregate variables identified by several

Waggoner $v$ Gibson, 647 F Supp 1102 (ND Tex 1986). But see, for example, Prendergast v Nelson, 199 Neb 97, 256 NW2d 657 (1977); Jones $v$ St. Board of Medicine, 97 Idaho 879, 55 P2d 399 (1976); Boyd $v$ Bulula, 877 F2d 1191 (4th Cir 1989), rev'g 647 F Supp 781 (WD Va 1986); Etheridge v Medical Center Hosp., 237 Va 87, 376 SE2d 525 (1989); LaMark $v$ NME Hosps., 542 S2d 753 (La App 1989), cert denied, 551 S2d 1334 (1989). See Randall R. Bovbjerg, Frank A. Sloan \& James F. Blumstein, Valuing Life and Limb in Tort: Scheduling "Pain and Suffering," $83 \mathrm{Nw} \mathrm{U} \mathrm{L} \mathrm{Rev} \mathrm{908,} 956-58$ (discussing caps generally); 968-74 (discussing their constitutionality) (1989). See also Kathryn L. Vezina, Constitutional Challenges to Caps on Tort Damages: Is Tort Reform the Dragon Slayer or is it the Dragon?, 42 Me L Rev 218 (1990); Jill Oliverio, To Cap or Not to Cap Damage Awards: That is the Constitutional Question, 91 W Va L Rev 519 (1988); Jesse M. Wagner \& Ronald E. Reiter, Damage Caps in Medical Malpractice: Standards of Constitutional Review, 1987 Det Coll L Rev 1005 (1987); Paul M. Barrett, Tort Reform Fight Shifts to State Court, Wall St J 27 (September 19, 1988).

103. Cal Civ Code $\$ 3333.2$ (West, 1970 \& Supp 1989). See Fein v Permanente Medical Group, 38 Cal3d 137, 695 P2d 665, 21' Cal Rptr 368 (1985), appeal dismissed, 474 US 892 (1985). See Bovbjerg, 22 U C Davis L Rev at 525 \& n 115 (cited in note 2).

104. Danzon, $49 \mathrm{~L} \&$ Contemp Probs at 77-78 (cited in note 72); Patricia M. Danzon, Medical Malpractice: Theory, Evidence, and Public Policy 82 (Harv U Press, 1985); Patricia M. Danzon \& Lee A. Lilliard, Medical Malpractice 26 (RAND, 1982). Contrast Sloan, 9 J Health Pol, Pol'y \& L at 633-34, 639 - 43 (cited in note 72); Sloan, Mergenhagen \& Bovbjerg, $14 \mathrm{~J}$ Health Pol, Pol'y \& L at 663 (cited in note 77). See generally Sloan \& Bovbjerg, Health Ins Ass'n Am Res Bull (cited in note 14).

Danzon found that caps on damages reduce the average severity of the claim by $23 \%$. Danzon, 49 L \& Contemp Probs at 72 (cited in note 72). More recently, Sloan, Mergenhagen \& Bovbjerg found that damage caps on total payments in particular achieved savings in claim payments of up to $39 \%$. Sloan, Mergenhagen \& Bovbjerg, $14 \mathrm{~J}$ Health Pol, Pol'y \& L at 678 (cited in note 77).

105. William P. Gronfein \& Eleanor D. Kinney, Controlling Large Medical Malpractice Claims: The Unexpected Impact of Damage Caps (recently accepted for publication in J Health Pol, Pol'y \& L).

106. In 1975, Michigan authorized voluntary, binding arbitration in lieu of a court trial, but this arbitration alternative has not been used to any significant extent. Michigan Commissioner of Insurance, Claims Experience and Market Conditions for Medical Malpractice Insurance 26 (1989). See also Rhoda M. Powser \& Frances Hamermesh, Medical Malpractice Crisis the Second Time Around: Why Not Arbitrate?, $8 \mathrm{~J}$ Legal Med 283 (1987); Mary Bedikian, Medical Malpractice Arbitration Act: Michigan's Experience with Arbitration, 10 Am J L \& Med 287 (1984-85). In 1975, Ohio enacted a $\$ 200,000$ limit on noneconomic damage except for wrongful death and mandated compulsory arbitration of malpractice claims. The Ohio Supreme Court immediately ruled that these reforms were unconstitutional; thus, they were never implemented. Simon $v$ St. Elizabeth Medical Center, 355 NE2d 903 (Ohio 1976). See Mary Ann Willis, Limitation on Recovery of Damages in Medical Malpractice Cases: $A$ Violation of Equal Protection?, 54 U Cin L Rev 1329 (1986); Thomas J. O'Connell \& Amy Tolnitch, Ohio's Attempt to Halt the Medical Malpractice Crisis: Effective or Meaningless?, 9 U Dayton L Rev 361 (1984).

107. Michigan, Ohio, and Indiana all adopted the two tort reforms (that is, shortened statutes of limitations and modified the common law collateral source rule) that Danzon found effective in reducing claim frequency and severity. Danzon, $49 \mathrm{~L} \&$ Contemp Probs at 71, 72, 77 (cited in note 72); Danzon, Medical Malpractice at 166 (cited in note 104). All three states tightened their statutes of limitations for malpractice in the mid-1970s. Ind Code Ann $\S 16-9.5-3-1$; Mich Comp Laws Ann $\S 600.5805$ (4) (West, 1987); Ohio Rev Code Ann $\$ 2305.10$ (Page, $1981 \& 1989$ Supp). All three states also modified the common law collateral source rule in the late 1980 s to require some offset of collateral payments from damage awards, although Ohio's rule does not apply to medical 
experts as having an important influence on claim severity, Indiana, Michigan, and Ohio are again reasonably similar. These variables include: level of urbanization; ${ }^{108}$ number of physicians per 10,000 persons; ${ }^{109}$ number of lawyers per 10,000 persons; ${ }^{110}$ per capita income; ${ }^{11}$ and ratio of surgeons to all physicians. ${ }^{112}$ With respect to these variables, Indiana's figures are lower than either Michigan's or Ohio's.113 Thus, one would expect that claim payments in Indiana would be lower than in either Michigan or Ohio.

In fact, however, the amount of compensation going to claimants with large malpractice payments in Indiana is, on average, substantially higher than in either Michigan or Ohio. ${ }^{114}$ The mean severity of Indiana's large claims ( $\$ 100,000$ or more) between 1975 and 1988 , in current dollars, was $\$ 404,832$; by contrast, Michigan's was $\$ 290,022$ and Ohio's was $\$ 303,220 .{ }^{115}$ The median payment for large claims was $\$ 435,283$ in Indiana, $\$ 180,000$ in Michigan, and $\$ 200,000$ in Ohio. ${ }^{116}$ Further, 27.9 percent of Indiana's PCF cases received the maximum allowable payment of $\$ 500,000$, while only 13 percent of Michigan's and Ohio's claims were paid at this level or above. 117

2. Operation of the Medical Review Panel. Surprisingly, medical review panels were invoked in only 11.7 percent of claims closed before December 31,1988 , although a panel had reviewed 1,452 open claims as of this date. ${ }^{18}$ For 52 percent of the PCF defendants for whom the PCF paid claims, no medical review panel was convened. ${ }^{119}$ Of the defendants in closed claims whose cases were considered by a medical review panel, only 189 (22.4 percent) were found to have committed malpractice. ${ }^{120}$

One reason for these startling findings regarding the use of the panel in closed claims is that the panel review process has proven to be quite timeconsuming. The average time between the filing of a complaint and the issuance of a final panel opinion is thirty-two months. ${ }^{121}$ Some anecdotal evidence suggests that slowness in forming and convening medical review

malpractice. Ind Code Ann $\S \S 34-4-36-1$ to 3 ; Mich Comp Laws Ann $\S 600.6301$; Ohio Rev Code Ann § 2317.45 .

108. Danzon, $49 \mathrm{~L} \&$ Contemp Probs at 75-76 (cited in note 72).

109. Sloan, 9 J Health Pol, Pol'y \& L at 638 (cited in note 72); Danzon, Medical Malpractice at 70-72 (cited in note 104).

110. Sloan, 9 J Health Pol, Pol'y \& $\mathrm{L}$ at 631 (cited in note 72).

111. Roger Feldman, The Determinants of Medical Malpractice Incidents: Theory of Contingency Fees and Empirical Evidence, 8 Atlantic Econ J 59, 61 -62 (1979).

112. Danzon, $49 \mathrm{~L} \&$ Contemp Probs at 74, 79 (cited in note 72)

113. Gronfein \& Kinney, J Health Pol, Pol'y \& $\mathrm{L}$ (cited in note 105).

114. Id. The Michigan and Ohio data derive from all large claims $(\$ 100,000$ or more) filed with the Medical Protective Company, Fort Wayne, Indiana between 1977 and 1988 . For the relevant period, the Medical Protective Company had about one-third of the market in Michigan and Ohio.

115. Id. The difference between these three means was highly significant at $p<.001$.

116. Id.

117. Id.

118. Indiana Patient's Compensation Fund at 3 (cited in note 69).

119 . Id.

120. Id.

121. Id at 5. See also Kemper, Selby \& Simmons, 19 Ind L Rev at 1133-35 (cited in note 36); Lester F. Murphy, Pitfalls in Medical Malpractice Panel Practice, 28 Res Gestae 178, 178-79 (1985). 
panels ultimately leads to delays in resolving malpractice claims, ${ }^{122}$ and perhaps also to the large backlog in open claims described above. ${ }^{123}$

These findings are quite interesting, given the role the medical review panel was designed to play in affording accessible expert review to determine liability early in a claim. However, as the experience with closed claims reveals, the medical review panel in fact plays an unexpectedly reduced role in the adjudication of malpractice claims. It should be noted that Pennsylvania and Florida courts have invalidated screening panels on grounds that they impose unconstitutionally impermissible delays. ${ }^{124}$ To the extent that delays in convening medical review panels contribute to the fact that only one-third of filed claims were closed from the start of reforms in 1975 through 1988 , the theories advanced in the Pennsylvania and Florida cases could prove persuasive in a future constitutional challenge to Indiana's reforms. It is also noteworthy that one Indiana trial court ruled the Act unconstitutional because of undue delays in the operation of Indiana's medical review panels; however, the Indiana Supreme Court reversed, concluding that the panel review process was not significantly longer than the disposition of lawsuits in the common law tort system. ${ }^{125}$

3. Impact of the By-Pass Amendment. As noted above, a 1985 legislative amendment authorized the filing of small claims $(\$ 15,000$ or less) directly in state court, thus by-passing the medical review panel. ${ }^{126}$ Some commentators anticipated that this authority would generate a flood of claims filed in court and effectively undercut Indiana's malpractice reforms. ${ }^{127}$ However, the bypass amendment has rarely, if ever, been used.128 Apparently, plaintiffs' attorneys are unwilling to acknowledge at the inception of a lawsuit that its value is less than $\$ 15,000$.

4. PCF Performance. Between 1975 and 1988, the PCF paid about 410 claims. The great majority of PCF claims were settled; only twenty-one claims were paid following court judgments, and one claim was settled after trial. ${ }^{129}$ Once claims reached the PCF, recoveries were generous. The mean payment was $\$ 405,297$ in real dollars, ${ }^{130}$ and the average severity of injury index was at

122. Kemper, Selby \& Simmons, 19 Ind L Rev at 1133 (cited in note 36); Murphy, 28 Res Gestae at $180-81$ (cited in note 121 ).

123. See notes $69-70$ and accompanying text.

124. Aldana v Holub, 381 S2d 231 (Fla 1980); Mattos v Thompson, 491 Pa 385, 421 A2d 190 (1980). See Bovbjerg, 22 UC Davis L Rev at $524 \&$ n 109 (cited in note 2).

125. Wamick v Cha, No SC-83-163 (Jasper County Superior Ct 1983), rev'd, Cha v Wamick, 476 NE2d 109 (Ind), cert denied, 474 US 920 (1985).

126. See note 34 and accompanying text.

127. See Kevin C. Murray, "Small Claims" Suits: Legislative Erosion of the Medical Malpractice Act, Marion County Med Soc'y Bull 10 (February 1986).

128. The Indiana Department of Insurance has no record of this procedure being used in any claim. (The Act requires health care providers and insurers to report the disposition of all malpractice claims. See note 65 and accompanying text.)

129. Indiana Patient's Compensation Fund at 3 (cited in note 69).

130. This figure differs from the mean large claim reported at note 115 and accompanying text because that figure included claims for which no additional payments were made from the PCF. 
the level that represents major permanent and total disability. About 14.9 percent of PCF claims involved injuries to infants at birth, while 29.8 percent of PCF claims were wrongful death cases.

The PCF's financial condition over the years has been troublesome. The PCF has always operated on a "pay-as-you-go" basis. Since 1975, the PCF surcharge has generated $\$ 150.8$ million in revenue, while the PCF has paid $\$ 135.3$ million in claim payments. ${ }^{131}$ In 1988 , the PCF collected $\$ 41.3$ million from the surcharge and paid $\$ 21.5$ million for claims, leaving a balance of $\$ 29.8$ million. ${ }^{132}$ A transfer of $\$ 7.2$ million from the reserves of the state's Medical Malpractice Joint Underwriting Commission rescued the PCF from insolvency in 1984. ${ }^{133}$ As discussed below, the surcharge on health care providers to finance the PCF has risen substantially since the Act's inception. ${ }^{134}$

5. Use of Structured Settlements. Periodic payments and associated structured settlements are ostensibly designed to ensure that damage awards will remain available to claimants for as long as they continue to need compensation. ${ }^{185}$ Structured settlements are particularly useful for claimants, especially because some evidence exists that a significant number of them exhaust large damage awards quickly, thus leaving their future needs largely unmet. ${ }^{136}$ On the other hand, structured settlements are attractive to insurers because the companies save by avoiding present cash payments and by using annuities and similar products from their other lines of business to help finance such settlements. In many Indiana claims, the use of periodic payments has resulted in creative structured settlements that benefit the claimants by permitting them to receive compensation worth more than the $\$ 500,000$ cap; nevertheless, a concern exists that, after attorneys' fees are paid, claimants actually receive very little in present compensation. ${ }^{137}$ Also, in a very few cases, serious abuses have occurred. ${ }^{138}$

In a judicial challenge brought by the Commissioner of Insurance, the Indiana Court of Appeals upheld two structured settlements entered into before 1985 in which insurers paid only $\$ 10,000$ at settlement, with the

131. Indiana Patient's Compensation Fund at 1 (cited in note 69).

132. Id.

133. GAO, Case Study on Indiana at 3 (cited in note 5).

134. See notes $146-47$ and accompanying text.

135. Comment, Making a Client Whole: Rhetoric or Reality?, 12 S U L Rev 281, 286 (1986) (authored by David Ferguson); Note, Periodic Payment Plans: Are Annuities Adequately Protecting the Personal Injury Plaintiff from Inflation, Providing Accurate Attorney's Fees and Promoting the Compensatory Goal of Our Tort Law System?, 12 Ohio N U L Rev 271, 272 (1985) (authored by James S. Marello); T. V. Mangelsdorf, Structured Settlements in Review: The Fundamental Concept, 4 Am J Trial Advoc 559, 561 (1981).

136. Note, 12 Ohio N U L Rev at 271 (cited in note 135).

137. Hallinan \& Headden, June 26,1990 Indianapolis Star at 9 (cited in note 6).

138. In one dramatic illustration of such abuses, St. Paul Fire and Marine Insurance Company agreed to settle a case with a claimant by paying $\$ 100,000$ to get the case to the PCF if the claimant agreed to repay St. Paul $\$ 25,000$ out of the settlement received. The claimant subsequently reported this arrangement to the Indiana Attorney General, and the Indiana Department of Insurance persuaded St. Paul to repay this $\$ 25,000$ to the claimant. See Joseph T. Hallinan, Insurer's Proposal for $\$ 25,000$ Loan Draws State's Ire, Indianapolis Star 8 (June 26, 1990). 
balance to be paid in future payments, noting that in seventy-five cases claimants gained access to the PCF following a structured settlement. ${ }^{139}$ Thus, the 1985 legislative amendments specifically authorizing structured settlements and establishing mandatory contribution amounts for insurers were actually intended to reform the practice regarding structured settlement that had evolved. 140

Since 1985 , periodic payments by primary insurers and the PCF have been used in structured settlements of PCF claims. Of the 264 PCF claims settled between 1985 and 1988, 32.6 percent involved periodic payments. Also, 23.9 percent of PCF claims during this period involved contributions from multiple health care providers or their insurers to activate the PCF. These data suggest that insurers continued to find the periodic payment option attractive in settling claims.

6. Litigation Costs. Under Indiana's system, attorneys' fees are limited for claims paid from the PCF, 141 ostensibly in order to maximize payments to claimants. While it appears that Indiana claimants with large claims pay less because of the cap on fees than they otherwise would under a common law system, some reason for concern exists because plaintiffs' attorneys have been able to charge expenses in addition to attorneys' fees, effectively increasing their total payments under the capped system.

Defense costs in Indiana compare favorably with defense costs in other states. The Medical Protective Company reports that its defense costs were markedly lower in Indiana than in either Ohio or Michigan. Specifically, between 1984 and 1988, Medical Protective paid 46 percent more in allocated loss adjustment expenses to close claims in Ohio and over 100 percent more in such expenses to close claims in Michigan. ${ }^{142}$

7. Malpractice Insurance Premiums. Given these trends, it is interesting that Indiana's malpractice insurance premiums have remained low compared to other states. According to a GAO study, Indiana health care providers continue to pay among the lowest malpractice insurance premiums in the nation. ${ }^{143}$ Specifically, Indiana physicians pay lower premiums than do physicians in the neighboring states of Ohio, Michigan, Illinois, and Kentucky, although with the PCF surcharge, physicians in comparable classes in Indianapolis, Indiana, now pay only slightly less than their counterparts in Cincinnati, Ohio, although they receive coverage for $\$ 500,000$ in damages compared to $\$ 100,000$ for their neighboring physicians. They also have total immunity from claims above $\$ 500,000$, indemnity that physicians in

139. See Eakin v Mitchell-Leech, 557 NE2d 1057 (Ind App 1990), transfer to US Supreme Court denied, No 45A02-8807-CV-213 (February 8, 1991).

140. See notes 49-50, 56-58 and accompanying text.

141. See note 51 and accompanying text.

142. Gronfein \& Kinney, J Health Pol, Pol'y \& L (cited in note 105).

143. US Gen Acct'g Office, Medical Malpractice: Insurance Costs Increased but Varied among Physicians and Hospitals 30-34, 60-69 (September 1986); GAO, Six Case Studies at 15-16 (cited in note 74). See also Sloan \& Bovbjerg, Health Ins Ass'n Am Res Bull at 5-6 (cited in note 14). 
neighboring states do not enjoy. ${ }^{144}$ It should be noted that physician carriers in Indiana offer occurrence insurance, which covers all claims that occurred during the policy period (whether or not the claim was actually brought within that period), as opposed to claims-made insurance, which covers only claims actually made during the policy period. Claims-made insurance is generally all that is available to physicians in Ohio, Michigan, and most other states. Nevertheless, the experience with imposing the surcharge to finance the PCF should dispel complacency about low insurance premiums in the long term. As discussed above, ${ }^{145}$ the PCF's solvency has been a persistent concern since the Act's inception. From 1975 through 1982, the surcharge on providers to support the PCF was 10 percent of malpractice premiums. ${ }^{146}$ By 1988, the surcharge increased to 125 percent. ${ }^{147}$

8. Subrogation, Statutory Liens, and the Collateral Source Rule. In a capped system, various remedies and rules accord rights to third parties to share in the claimant's tort recovery or require reductions in the claimant's recovery to adjust for compensation from other sources. The operation of these devices raises important concerns. These rights and rules may be analytically appealing in an abstract sense because they appear to prevent possible windfalls to claimants. However, one must question their fairness in a capped system. When a damage cap both sets a categorical limit on what can be awarded and permits attorneys to be paid off the top of awards, claimants may actually receive very little after third parties have received reimbursement of their expenses.

Indiana has adopted several statutory lien provisions to permit hospitals, ${ }^{148}$ workers compensation insurers, ${ }^{149}$ and the state Medicaid program $^{150}$ to obtain reimbursement from plaintiff's tort recoveries. Indiana common law recognizes the right of health insurers, pursuant to contract, to recover reimbursement for medical expenses from tort recoveries gained by their insureds. ${ }^{151}$ Also, as noted above, ${ }^{152}$ Indiana's legislature abrogated the common law collateral source rule, which prohibits the admission at trial of evidence of other sources of compensation available to the plaintiff. ${ }^{153}$ These

144. Mullen, Update at S-15, chart F (cited in note 24).

145. See notes 131-34 and accompanying text.

146. Indiana Patient's Compensation Fund at 61 (cited in note 69).

147. Id.

148. Ind Code Ann \$ 32-8-26-1.

149. Id at $\S \S 22-3-2-13,22-3-7-36$. See Dearing v Perry, 499 NE2d 268 (Ind App 1982); Hagerman $v$ Mutual Hosp. Ins., Inc., 175 Ind App 293, 371 NE2d 394 (Ind App 1978). See generally Robert E. Keeton \& Alan I. Widiss, Insurance Law: A Guide to Fundamental Principles, Legal Doctrines, and Commercial Practices § 3.10(a)(7), 228-32 (West, 1988).

150. Ind Code Ann $\$ 12-1 \cdot 7-24.6$.

151. See, for example, Costello v Mutual Hosp. Ins., Inc., 441 NE2d 506 (Ind App 1982); Hagerman, 175 Ind App 293, 371 NE2d 394 . See generally Keeton \& Widiss, Insurance Law \& 3.10(a)(7), at 22832 (cited in note 149 ).

152. See note 12 and accompanying text.

153. Ind Code Ann \$ 34-4-36-1. See generally Wilkins, 20 Ind L Rev 399 (cited in note 12). Under Indiana's rule, the trier of fact calculates reductions in awards for collateral benefits received. Life insurance payments and other death benefits, insurance benefits directly paid for by the plaintiff 
authorities have been invoked in many medical malpractice claims, including 8 percent of PCF claims, for a total of $\$ 2,256,596$. The Indiana Medicaid program has imposed the great majority of these liens, while Blue Cross and Blue Shield of Indiana, Inc., the Medicare program, and hospitals have imposed a few.

The operation of these rights of third parties in a capped system indeed raises fundamental questions of fairness, as Indiana's actual experience demonstrates. There have been instances where claimants have received very little from a large recovery because third parties and the plaintiff's attorney have been paid first. ${ }^{154}$ Particularly disturbing is the interaction of the damage cap with these statutory liens. Arguably, the cap is designed to hold down claim severity and thereby make malpractice insurance more affordable for health care providers. Thus, the cap represents a transfer of wealth from a few claimants with very large claims to the health care providers that collectively finance the system for compensating malpractice injury. Such a transfer is appropriate as long as claimants are not harmed substantially.

or his family, and governmental benefits received by the plaintiff before trial are excluded, but worker's compensation is not. Ind Code Ann $\$ 34-4-36-2$.

154. The following letter from a 43-year-old PCF claimant to the Indiana Department of Insurance dramatically illustrates the injustice that can result from imposing such liens in a capped system:

During April of 1981, I became a victim of medical malpractice. . . . To meet his one hundred thousand dollar $(\$ 100,000.00)$ obligation, Dr. [Defendant] purchased an annuity that will mature in fifteen (15) years. According to my attorney, I will be awarded four hundred thousand dollars $(\$ 400,000.00)$ on the fifteenth of this month (July 15 th, 1987). I feel it is necessary to write to you to show you how that amount will be divided up and thus showing the injustice of the state's medical malpractice system.

During the last five and one-half (5.5) years, the Indiana State Department of Public Welfare (through Medicaid) has spent two hundred thirty-nine thousand eighty-two dollars and forty-two cents $(\$ 239,082.42)$ for my care as of mid-June 1987 . A lien for this amount has been filed and must be honored accordingly. The attorneys' fees are one hundred thousand dollars $(\$ 100,000.00)$ plus expenses incurred for this case. Those expenses have been set at thirty thousand dollars. The balance is the actual compensation I'll receive until the annuity matures. The following table illustrates the settlement's division.

$\begin{aligned} \$ 400,000.00 & \text { Amount to be received July } 15 \\ 239,082.42 & \text { To the State Welfare Department } \\ 130,000.00 & \text { Attorney fees and expenses }\end{aligned}$

$30,917.58$

TO THE VICTIM

By July 15th, Medicaid will probably increase the lien by two thousand dollars $(\$ 2000.00)$. The Malpractice incident resulted in the loss of function in my left arm and both legs. I also lost bladder and bowel control making the possibility of employment almost impossible. I'm living in a nursing home and my part of the settlement will not cover one year's expenses. This means I'll be back on Medicaid and in fifteen (15) years (when the annuity matures) it will be claimed through a lien by Medicaid.

I'm forty-three (43) years old. If financially able to do so I could live on my own with an attendant, but I've lost more than bodily functions. I've also lost independence and my liberty. That loss of independence and liberty was through medical malpractice yet as the victim, I'll not be allowed to regain my liberty and independence through just compensation.

Letter of Malpractice Claimant to Indiana Commissioner of Insurance (July 4, 1987). This letter is available from The Center for Law and Health, Indiana University School of Law-Indianapolis, Indianapolis, Indiana 46202. 
However, poor claimants on Medicaid are disproportionately victimized by these liens.

When third parties are placed ahead of the claimant who, to serve other societal goals, already must expect limited compensation, a clear ethical issue emerges: whose interest is more deserving? Medicaid liens raise more complicated issues, because Medicaid eligibility rules require applicants to deplete resources before becoming eligible for benefits. Nevertheless, future medical expenses represent only part of special and general damages, which also include losses due to inability to work, pain and suffering, ${ }^{155}$ or, in the case of wrongful death, losses to the survivors. ${ }^{156}$ Allowing third parties to receive full payment from claimants' damage awards under a capped system embodies the erroneous assumption that claimants' damages are basically medical expenses rather than these other types of equally important items of damage.

\section{IV}

\section{No-Fault by Accident?}

Indiana's claims are adjudicated and paid under the most comprehensive and severe set of insurance and tort reforms in the nation. ${ }^{157}$ Yet Indiana's malpractice reforms operate in a way that softens the expected impact of these reforms and results in a comparatively generous compensation system. In Indiana's system, a variety of subtle incentives appear to encourage the insurers of health care providers to settle claims, particularly large claims, with little concern about the defendant's fault.

Insurers are apparently pushing claims involving serious injury to the PCF by agreeing to pay claimants the requisite amount to make cases eligible for $\mathrm{PCF}$ payment. If a structured settlement can be arranged with other insurers contributing to the initial settlement, the insurer is in an even better position. In any event, upon settlement, the insurer has exhausted the limits of the insured's primary policy and no longer has any interest or real obligation to provide a defense to the insured. Given that the medical review panel is an optional proceeding, insurers have much to gain and little to lose by forgoing a costly defense before the review panel and instead expeditiously pushing a borderline case to the PCF.

The fact that, compared to the GAO study, fewer Indiana claims are paid between $\$ 25,000$ and $\$ 100,000$, more Indiana claims are paid at $\$ 100,000$ and above, and only fourteen claims fell between $\$ 75,000$ and $\$ 100,000$ in a twelve-year period ${ }^{158}$ is persuasive evidence that insurers may be pushing substantial claims to the PCF that ordinarily would be settled for under $\$ 100,000$. Insurers are apparently willing to add a few dollars to get a claim

155. Dan B. Dobbs, Handbook on the Law of Remedies $\$ 8.1,540-51$ (West, 1973).

156. Id at $\$ 8.3,556-57$.

157. See Sloan \& Bovbjerg, Health Ins Ass'n Am Res Bull at 19 (cited in note 14).

158. See notes $81-82$ and accompanying text. 
to the PCF in order to terminate their obligation to defend the claim and pay related expenses.

The statutory constraints on what can be considered in a PCF decision to pay a claim also uniquely affect the adjudication and resolution of large malpractice claims. By law, the PCF can consider only the amount of the claimant's damages; it must assume that the defendant's liability is admitted. 159 Consequently, the factors that influence the ultimate payment of claims in the common law tort system, such as the jury's final decision on liability or the expenses involved in pressing a claim through trial, ${ }^{160}$ are not considered in establishing the amount of compensation for the claimant.

One crucial result of these incentives in Indiana's system is that a state-run insurance fund is paying large sums of money to most PCF claimants without a formal determination of fault. As a practical matter, the only required indications of a defendant's liability are (1) a private decision by a malpractice insurer-or several insurers in a structured settlement-that its exposure (including likely litigation costs) is such that it will pay a sizable sum to the claimant, and (2) the PCF's subsequent assessment of the value of the claimant's damages.

Is this no-fault by accident? The distinguishing characteristics of no-fault schemes are the imposition of liability for designated injuries regardless of the defendant's fault, limits on damages generally paid according to a fixed schedule, and a broader spectrum of compensable injuries for which payment is not contingent on fault. ${ }^{161}$

159. See note 62 and accompanying text.

160. Ross, Settled Out of Court at 111 (cited in note 53).

161. In the mid-1970s, when sharply increased severity and frequency of medical malpractice claims spawned a "crisis" in the availability and affordability of medical malpractice insurance, tort scholars looked to the no-fault concept as a potential solution. See, for example, Clark C. Havighurst \& Laurence R. Tancredi, "Medical Adversity Insurance"-A No-Fault Approach to Medical Malpractice and Quality Assurance, 51 Millbank Mem Fund Q 125 (Spring 1973); Robert E. Keeton, Compensation for Medical Accidents, 121 U Pa L. Rev 590 (1973); Clark C. Havighurst, Medical Adversity Insurance: Has its Time Come?, 1975 Duke L J 1233; Jeffrey O'Connell, An Alternative to Abandoning Tort Liability: Elective No-Fault Insurance for Many Kinds of Injury, 60 Minn L Rev 501 (1976). See also Albert A. Ehrenzweig, Compulson "Hospital Accident" Insurance: A Needed First Step toward the Displacement of Liability for "Medical Malpractice," 31 U Chi L Rev 279 (1964). Several scholars concluded that the no-fault concept was not suitable for medical malpractice because of the difficulty and cost involved in distinguishing an injury for which compensation would be paid from an unavoidable bad result due to the claimant's underlying illness. Keeton, $121 \mathrm{U}$ Pa L Rev 590 (cited in this note); Guido Calabresi, The Problem of Malpractice-Trying to Round Out the Circle, and Richard A. Epstein, Medical Malpractice: Its Cause and Cure, both in Simon Rottenburg, ed, The Economics of Medical Malpractice at 233, 239 and $261-62$ respectively (Am Enterprise Inst for Pub Pol'y Res, 1978).

But since the 1970 s, scholars have maintained that these problems could be ironed out and medical malpractice claims could still be resolved through some type of no-fault scheme. Laurence R. Tancredi, Designing a No-Fault Alternative, 49 L \& Contemp Probs 277 (Spring 1986); Jeffrey O'Connell, Neo-No-Fault Remedies for Medical Injuries: Coordinated Statutory and Contractual Alternatives, 49 L \& Contemp Probs 125 (Spring 1986). See generally Ronald S. Latz, No-Fault Liability and Medical Malpractice: A Viability Analysis, $10 \mathrm{~J}$ Legal Med 479 (1989). In the late 1970s, the American Bar Association seriously explored the concept and developed proposals. Am Bar Ass'n, Designated Compensable Event System: A Feasibility Study 5 (Am Bar Ass'n, 1979). At least two states, Virginia in 1987 and Florida in 1988, adopted a no-fault-like system for adjudication and compensation of birth injuries. Va Code $\$ \S 38.2-5000$ to -5021 (1989); Fla Stat Ann $\$ \S 766.301$ to .316 (West, 1990). See Richard A. Epstein, Market and Regulatory Approaches to Medical Malpractice: The Virginia Obstetrical No- 
Indiana's system does contain some of the central features of a no-fault compensation system. Perhaps most importantly, Indiana's system weakens the requirement that the plaintiff prove fault on the part of the defendant before recovery, as evidenced by the fact that relatively few medical review panels have been convened to adjudicate liability. As noted above, a medical review panel was convened in only 11.7 percent of claims closed from 1975 through 1988. ${ }^{162}$ Furthermore, for over half (52 percent) of the defendants for whom the PCF paid claims during this period, no medical review panel was ever convened. ${ }^{163}$

The adjudication process is somewhat more streamlined in Indiana, particularly for large PCF claims. Adjudication costs are lower in Indiana compared to neighboring states, ${ }^{164}$ and claimant attorneys' fees for large claims are statutorily fixed. ${ }^{165}$ In addition, Indiana claims overall are adjudicated in a somewhat shorter time frame (nearly two months shorter) than claims nationally. ${ }^{166}$

Finally, Indiana's system pays more claims at more generous levels (which is not necessarily characteristic of a no-fault system), but is constrained by the upper limit imposed by the cap. As discussed above, Indiana's mean largeclaim severity between 1975 and 1988 was more than $\$ 100,000$ greater than either Michigan's or Ohio's, and nearly twice the number of Indiana claims over $\$ 100,000$ were paid at the $\$ 500,000$ level. ${ }^{167}$ Further, Indiana had comparatively more large claims, with proportionately fewer claims settling for under $\$ 100,000$ than the national sample. ${ }^{168}$ Also, of claims brought, more claims are paid in Indiana compared to other states-a trend more typical of no-fault systems. ${ }^{169}$

Fault Statute, 74 Va L Rev 1451 (1988); Jeffrey O'Connell, Pragmatic Constraints on Market Approaches: A Response to Professor Epstein, 74 Va L Rev 1475 (1988). One group of the various no-fault proposals and enacted plans is characterized as neo-no-fault early compensation schemes. See, for example, Jeffrey O'Connell, Offers That Can't Be Refused: Foreclosure of Personal Injury Claims by Defendants' Prompt Tender of Claimants 'Net Economic Losses, $77 \mathrm{Nw}$ U L Rev 589 (1982); O'Connell, 49 L \& Contemp Probs 125 (cited in this note); W. Henson Moore \& John S. Hoff, H.R. 3084: A More Rational Compensation System for Medical Malpractice, 49 L \& Contemp Probs 117 (Spring 1986). A second category is limitedno-fault, such as specified events schemes. Am Bar Ass'n, Designated Compensable Event System (cited in this note); Tancredi, 49 L \& Contemp Probs 277 (cited in this note); Havighurst \& Tancredi, 51 Millbank Mem Fund Q 125 (cited in this note). See also James A. Henderson, Jr., The Virginia BirthRelated Injury Compensation Act: Limited No-Fault Statutes as Solutions to the "Medical Malpractice Crisis," in Victoria P. Rostow \& Roger J. Bulger, eds, 2 Medical Professional Liability and the Delivery of Obstetrical Care 194; 196 (Nat'l Acad Press, 1989). A third group is pure no-fault. See Latz, $10 \mathrm{~J}$ Legal Med at 488-92 (cited in this note); Ehrenzweig, $31 \mathrm{U}$ Chi L Rev 270 (cited in this note); William H. L. Dornette, Medical Injury Insurance-A Possible Remedy for the Malpractice Problem, in Nicholas N. Kittrie, Harold L. Hirsh \& Glen Wegner, eds, Medicine, Law and Public Policy 26 (AMS Press, 1975).

162. See note 118 and accompanying text.

163. See note 119 and accompanying text.

164. See note 142 and accompanying text.

165. See note 151 and accompanying text.

166. See note 85 and accompanying text.

167. See notes 116-17 and accompanying text.

168. See notes 81-82 and accompanying text.

169. See note 80 and accompanying text. 
Admittedly, the disposition of claims in Indiana, including large claims, is similar to the process for settling claims in a common law tort system, with Indiana's PCF playing the role of a private secondary insurer. Nevertheless, the unique incentives in Indiana's system that encourage insurers to push claims to the PCF without medical review, and the PCF's mandate to consider only damages in determining compensation levels, represent crucial departures from the common law tort system and encourage insurers to behave more as if operating under a no-fault system. The unique distribution of claim severity and the comparative generosity in payment levels for medium and large claims, ${ }^{170}$ coupled with the infrequent use of the panel review process (at least for closed claims), ${ }^{171}$ confirm the impression that such incentives are operating in Indiana's system, and that the settlement process under Indiana's system differs from that under a common law, fault-based system.

In sum, by adjudicating and resolving claims, although not particularly expeditiously, through an informal process supervised by an administrative agency, Indiana's system reduces the need to prove fault. The interesting feature of Indiana's system is that the design and operation of the PCF and the rules governing eligibility for payment of claims by the PCF create incentives for insurers to behave as if Indiana had a no-fault system without an explicit legal mandate to do so.

Indiana's system also offers intriguing opportunities to implement a new generation of reforms, such as a designated compensable events scheme proposed by leading torts scholars. ${ }^{172}$ Specifically, Indiana could easily incorporate a designated events scheme into its system expressly for PCF claims, since the PCF process already identifies large claims that would be the most likely candidates for the application of such a scheme. Upon selecting and installing a particular designated events scheme, the Department of Insurance staff could review cases for conformity with the criteria for the compensable events and decide whether compensation was warranted. These cases could then be referred to a panel of experts retained by the PCF to review each case and decide on compensation under the designated events scheme and an associated schedule of damages.

The centralized nature of Indiana's system simplifies legislative or regulatory changes that would be needed to implement no-fault reforms,

170. See notes $81-84,114-17$ and accompanying text.

171. See notes $118-20$ and accompanying text.

172. A designated compensable events system would identify a limited set of adverse outcomes occurring with some frequency during medical treatment, fix an amount of damages specific to each outcome, and award that amount to a patient whenever he or she suffers the particular outcome. Such a system would eliminate inquiry regarding whether the physician was at fault for the injury. See Laurence R. Tancredi, Randall R. Bovbjerg \& Dan S. Gaylin, Obstetrics and Malpractice: Evidence on the Performance of a Selective No-Fault System (submitted for publication); Laurence R. Tancredi \& Randall R. Bovbjerg, Rethinking Responsibility for Patient Injury: Accelerated-Compensation Events, A Malpractice and Quality Reform Ripe for a Test, 54 L \& Contemp Probs 147 (Spring 1991); Tancredi, 49 L \& Contemp Probs 277 (cited in note 161); Am Bar Ass'n, Designated Compensable Event System (cited in note 161); Havighurst \& Tancredi, 51 Millbank Mem Fund Q 125 (cited in note 161). 
which have heretofore been relegated to theory because of the practical difficulties posed by implementation. The supervision of the system by the Department of Insurance ensures the accountability and performance to which the public is entitled. By making compensation faster and more predictable, such reforms might more directly address the need for adequate and expeditious compensation of medical accident victims than does Indiana's existing system currently.

\section{$\mathrm{V}$}

\section{ConClusion}

Indiana's experience, particularly with large claims, suggests that relatively subtle administrative arrangements for the management of claims at the state level may influence whether claimants are treated fairly by a system that is tightly structured to control claim severity and thus the price and availability of malpractice insurance for providers. The operation of the Indiana system provides exciting opportunities for further experimentation with no-fault reforms. Nevertheless, Indiana's experience should caution reformers, critics, and other observers to look closely at the more mundane, detailed aspects of how the supposedly strict, insurer- and provider-oriented reforms exemplified in Indiana's current malpractice system operate in practice before reaching intuitively appealing conclusions about the fairness of the reforms or the need for additional reforms. 


\section{APPENDIX}

Data from this study is from the Indiana Malpractice Claims Data Base ("IMDB") obtained from all Indiana malpractice claims filed with the Indiana Department of Insurance from 1975 through 1988. Collected data fall in three categories: claims, claimants, and defendants. Data on claims include: (1) filing date; (2) date of final disposition; (3) allegations of negligence; (4) medical review panel decision, if any; (5) results of court proceedings, if any; (6) amount of award, if any; and (7) nature of final disposition. On claimants, the data include: (1) demographic characteristics of claimants, for example, age, sex, marital status, residential county, and zip code; (2) the medical condition giving rise to the malpractice, including initial diagnosis and any misdiagnosis; (3) any operations or procedures performed on the claimant; (4) injuries sustained during the incident of alleged malpractice, including initial and ultimate injuries; and (5) severity of injury. On physician defendants, the data include: (1) date of licensure; (2) medical education; (3) location of practice; (4) self-reported specialty; (5) nature of medical practice; and (5) board certification. For hospital defendants, data include: (1) number of beds; (2) type of corporate control; (3) teaching status; (4) geographic location; and (5) case mix.

For claimant characteristics and damage awards, the data collection instrument developed by GAO for its study of claims closed in 1984 was used. ${ }^{1}$ Whenever possible, information on diagnosis, procedures performed, and injuries came directly from the patient's hospital chart for the treatment episode in which the alleged malpractice occurred. A registered medical records administrator coded data on diagnoses, injuries, procedures, and operations using the ICD-9-CM disease classification system. ${ }^{2}$

For allegations of negligence, the classification categories developed by the Risk Management Foundation of the Harvard Medical Institutions were used. $^{3}$ The Risk Management Foundation protocols provide for seventyseven individual allegations of negligence, which may be grouped into twelve larger categories: (1) diagnosis; (2) anesthesia; (3) surgery; (4) medication selection; (5) medication administration; (6) intravenous procedures; (7) obstetrics; (8) treatment; (9) patient monitoring; (10) biomedical equipment; (11) blood products; and (12) other allegations not elsewhere classified.

Severity of injury was classified according to the nine-level system developed by the National Association of Insurance Commissioners. ${ }^{4}$

1. US Gen Acct'g Office, Medical Malpractice: Characteristics of Claims Closed in 1984 (April 1987).

2. US Dep't of Health and Human Services, Health Care Fin Admin, ICD-9-CM: International Classification of Diseases, 9th Revision, Clinical Modification (1980).

3. See Harvard Risk Management Foundation, Risk Management Foundation Information System (1987).

4. Nat'l Ass'n Ins Commissioners, Medical Malpractice Closed Claims, 1975-1978 (1980). For a listing of the nine categories of injury, see note 94 in main text. 


$$
\text { - }
$$

